\title{
PRIMARY EMISSION RATIOS OBTAINED FROM THE MONITORING OF CRITERIA POLLUTANTS IN REBOUÇAS TUNNEL, RIO DE JANEIRO, BRAZIL.
}

\author{
ALMEIDA, José Claudino; MOREIRA, Andrea1; MOREIRA, Lino'; ARBILLA, Graciela² \\ ${ }^{1}$ PETROBRAS/CENPES, Monitoramento Atmosférico, Cidade Universitária, Quadra 7, Ilha do Fundão, Rio de \\ Janeiro, RJ, Brasil \\ ${ }^{2}$ Departamento de Físico-Química, Instituto de Química, Universidade Federal do Rio de Janeiro, Sala 408, CT \\ Bloco A, Cidade Universitária, 21949-900, Rio de Janeiro, RJ, Brasil \\ *e-mail: graciela@iq.ufrj.br
}

Received 24 August 2007; received in revised form 12 November 2007; accepted 23 November 2007.

\section{RESUMO}

As medidas das concentrações de poluentes em túneis refletem as reais características das fontes móbiles permitindo estabelecer estratégias de controle a fim de reduzir emissões e a formação de poluentes secundários. Os níveis de concentração de $\mathrm{CO}, \mathrm{NOx}, \mathrm{SO}_{2}$ e $\mathrm{PM}_{10}$ (material particulado com diâmetro menor que $10 \mu \mathrm{m}$ ) foram registrados no interior do Túnel Rebouças, numa estação de monitoramento contínuo instalada aproximadamente a $1.500 \mathrm{~m}$ da entrada. Os dados reportados são valores horários médios para o ano de 2002, considerando apenas os dias úteis, excluindo os finais de semana. Em termos dos ciclos diários típicos, os maiores níveis de concentração aconteceram perto dos picos de fluxo veicular e os poluentes legislados apresentaram uma boa correlação com $\mathrm{CO}$, como esperado, dado sua origem comum na combustão veicular. Os valores horários médios para $\mathrm{CO}$ foram de 10 a 50 ppm e a relação média CO/NO (na base ppm) foi de 0,011 , em bom acordo com dados preliminares para outros locais de Brasil. As concentrações de NO foram entre menos de $1 \mathrm{ppm}$ e aproximadamente $4 \mathrm{ppm}$ e essa forma foi claramente a dominante entre os óxidos de nitrogênio (NOx) encontrados no túnel, respondendo por mais do $90 \%$ da soma de $\mathrm{NO}$ e $\mathrm{NO}_{2}$. Os óxidos de enxofre (medidos como $\mathrm{SO}_{2}$ ) e as partículas inaláveis se encontraram em concentrações entre 55 e $140 \mathrm{ppb}$ e aproximadamente 60 a 250 to $250 \mu \mathrm{g} \mathrm{m}^{-3}$, respectivamente, para os perfis anuais integrados.

Palavras-chave: emissões veiculares, poluentes legislados, túnel

\section{ABSTRACT}

Meassurements of pollutants concentrations in tunnels can reflect the actual characteristics of mobile sources in order to provide a control strategy to reduce emissions and secondary pollutants formation. Concentration levels of $\mathrm{CO}, \mathrm{NOx}, \mathrm{SO}_{2}$ and $\mathrm{PM}_{10}$ (particulate matter less than $10 \mu \mathrm{m}$ in diameter) were recorded inside Rebouças Tunnel, in a continuous monitoring station installed at about 1,500 $\mathrm{m}$ from the entrance. The reported data are the hourly average values through the year of 2002, bracketed only for the weekdays, weekends excluded. In terms of typical day cycles, the highest concentration levels occur close to traffic peaks and the criteria pollutants show good overall correlation levels with $\mathrm{CO}$, as expected, given their common combustion-bound origin. $\mathrm{CO}$ hourly averages ranged from 10 to $50 \mathrm{ppm}$ and the average $\mathrm{CO} / \mathrm{NO}$ ratio (on a ppm basis) was 0.011 , in good agreement with preliminary data for other locations in Brazil. NO concentration levels ranged from less than $1 \mathrm{ppm}$ to about $4 \mathrm{ppm}$ and this form is by far the dominant for nitrogen oxides (NOx) found in the tunnel, accounting for more than $90 \%$ of the sum of $\mathrm{NO}$ plus $\mathrm{NO}_{2}$. Sulfur oxides (measured 
as $\mathrm{SO}_{2}$ ) and inhalable particles concentrations ranged from 55 to $140 \mathrm{ppb}$ and about 60 to $250 \mu \mathrm{g} \mathrm{m}^{-3}$, respectively, for the composite annual profiles.

Keywords: vehicle emissions, criteria pollutants, tunnel

\section{Introduction}

The city of Rio de Janeiro represents the second largest running fleet in Brazil: roughly 1,5 million passenger cars and commercial vehicles being composed of approximately $82 \%$ LDV (Light-Duty Vehicles), powered mostly by a mixture of motor gasoline and ethanol, 12\% HDV (Heavy- Duty Vehicles, mainly buses and trucks) running on diesel and $6 \%$ motorcycles (DETRAN, 2006). According to the most recent available official emission inventory, approximately $76 \%$ of the total air pollution load of $\mathrm{CO}, \mathrm{SO}_{2}, \mathrm{NOx}(\mathrm{NO}$ $+\mathrm{NO}_{2}$ ) and $\mathrm{PM}_{10}$ (particulate matter less than 10 $\mu \mathrm{m}$ in diameter) are direct contributions of the mobile sources (FEEMA, 2006). In the case of CO, $98 \%$ comes from vehicles. Another important issue to be considered in terms of local environmental policies is the age of the car fleet: according to the traffic authorities in Rio de Janeiro, over $50 \%$ of the running fleet is above 10 years old (DETRAN, 2006). These figures, despite the obvious scarcity of reliable information on atmospheric emissions and the intrinsic lack of accuracy of the data available, reinforce the importance of a monitoring program provided on a regular basis to support the elaboration of local sound and cost-effective air quality management and control policies.

As discussed by Hsieh et al. (1999), tunnel studies are used to measure emissions from motor vehicles. The tunnel atmosphere can represent a mobile source since it is dominated by vehicles emissions. Therefore, meassurements of pollutants concentrations in tunnels can reflect the actual characteristics of mobile sources in order to provide a control strategy to reduce emissions and secondary pollutants formation.

Given its relevance as an urban transportation artery and the prevailing contribution of LDV in the local fleet and some other important characteristics further detailed in the present paper, Rebouças Tunnel was chosen as the monitoring site for this study. A complete monitoring station was installed inside the gallery connecting Cosme Velho to Rio Comprido, or respectively the South and North wards of Rio de
Janeiro.

One of the main advantages of sampling inside an urban tunnel is the more realistic picture of the local fleet profile, given the absence or minimization of external perturbations, such as atmospheric scavenging processes, that may interfere by changing the profile of the local primary emissions. This is actually one of the main difficulties of assessing the atmospheric emissions in the open environment. It is worth mentioning that the advantage of this type of study, as opposed to sampling emissions directly from a chassis dynamometer facility, for instance, is the adherence of the measured concentration levels to the emissions coming from the active fleet, given its current status and actual maintenance conditions.

\section{Materials and Methods}

Rebouças Tunnel was chosen as the primary monitoring site for the assessment of vehicular emissions coming from the active fleet in Rio de Janeiro due to a combination of important factors, such as:

1) The high daily traffic volume - ranging from 180,000 to 190,000 vehicles day ${ }^{-1}$, this Tunnel being the main artery connecting the South and North zones of the city;

2) The fleet profile is practically constant with time, as shown later and the LDV fleet represents roughly $95 \%$ of the local traffic. It is worth to mention that the main goal of the present study is to assess the contributions of the fleet driven by gasoline;

3) The tunnel extension of approximately $2,840 \mathrm{~m}$ in both galleries grants the minimization (or absence) of external influences, thus enabling the assessment of the average bulk of primary emissions coming from the local fleet.

The tunnel has four galleries: the two main galleries are L1 (northwards) and L2 (southwards) with an approximate length each of 2,040 m, linking Humaitá to Cosme Velho. There 
are also two secondary galleries, R1 (northwards) and R2 (southwards), connecting Cosme Velho to Rio Comprido, with 800 m length each roughly.

The pollutants were sampled inside the Tunnel (gallery L1), in a continuous monitoring station installed at about $1,500 \mathrm{~m}$ from the entrance, recording concentration levels of $\mathrm{CO}$, $\mathrm{NOx}, \mathrm{SO}_{2}$ and $\mathrm{PM}_{10}$. These compounds are considered criteria pollutants, that is pollutants which have documented effects on people, plants, animals and materials, and for which national ambient quality standards were determined. In Brazil these standards were determined by CONAMA (1990).

CO concentration levels were measured by infrared spectroscopy (SERES Model CO2000); $\mathrm{NOx}\left(\mathrm{NO}+\mathrm{NO}_{2}\right)$ were measured by chemiluminescence (SERES Model NONOX2000); SO2 was analyzed by Ultra-Violet fluorescence (SERES Model SF2000). $\mathrm{PM}_{10}$ was measured resorting to a $\beta$ - attenuation monitor (manufactured by Andersen instruments). Calibrations of the continuous analyzers $\left(\mathrm{NO}_{x}\right.$, $\mathrm{CO}$ and $\mathrm{SO}_{2}$ ) involved the use of an API Model 700 multicalibrator together with a cylinder of NIST-traceable certified gas mixture $(51.5 \mathrm{ppm}$ $\mathrm{NO}, 5130 \mathrm{ppm} \mathrm{CO}$ and $51.5 \mathrm{ppm} \mathrm{SO} \mathrm{S}_{2}$ in nitrogen), manufactured by Scott-Marrin.

Data storage was provided by Datalogger, manufactured by Campbell, model CR10X. On average once to twice a week the station was visited by the field technician, in order to take the necessary inspection and maintenance actions, download the data and proceed the required zero/span calibration/verification routines in locu. More sophisticated interventions such multicalibration, drift, linearity checking and equipment cleaning required to take each monitor to an external facility, in which the procedures would be executed in a more convenient way. One of the most serious problems was the lack of spare or back-up at the time for the equipments in operation; once the equipment was being checked or out for repair there would unfortunately be no spare or substitution, thus justifying the elevated percent of lags or blanks in our monitoring time series. Other details may be found in Almeida (2004).

The tunnel ventilation system is currently composed of 78 fans lumped in groups. The original project included the intake of fresh, external air from the entrance of the tunnel and its supply into the galleries from the tunnel ceiling, thus granting the flow of local background air onto the vehicles inside Rebouças. This project was much similar to the ventilation systems commonly adopted in the U.S., but unfortunately it granted no financial support. Up to this date, the tunnel ventilation system installed is composed of the fans, lodged close to the tunnel ceiling, that have the function of pushing air towards the traffic flow. Gallery $\mathrm{L} 1$ is considered to be the most critical in terms of pollution load and currently operates with 55 fans throughout its whole length.

\section{Results and Discussion}

Figure 1 illustrates the daily hourly variations of the traffic inside Rebouças Tunnel Gallery L1, flowing northwards, all vehicle categories included. . This graph is a composite plot for the average traffic counting throughout the year, bracketed only for the weekdays, weekends excluded, and represent the flow rate of vehicles per hour. The values shown correspond to the one-hour average traffic flow for roughly 20 weekdays per month throughout the year, thus composing a typical day cycle. As a rule, there is very little traffic during the very late hours of the night and early hours of day, with an uptake of traffic flow approaching 06:00 A.M; traffic peaks off roughly at 07:30 A.M. with a secondary peak at 05:30 P.M. Between these hours, the traffic flow profile is rather flat with time. After the afternoon peak, the volume flow shows a downward trend. Traffic peaks correspond to the hours of the day when the flux of vehicles between the South and North zones of the city is higher.

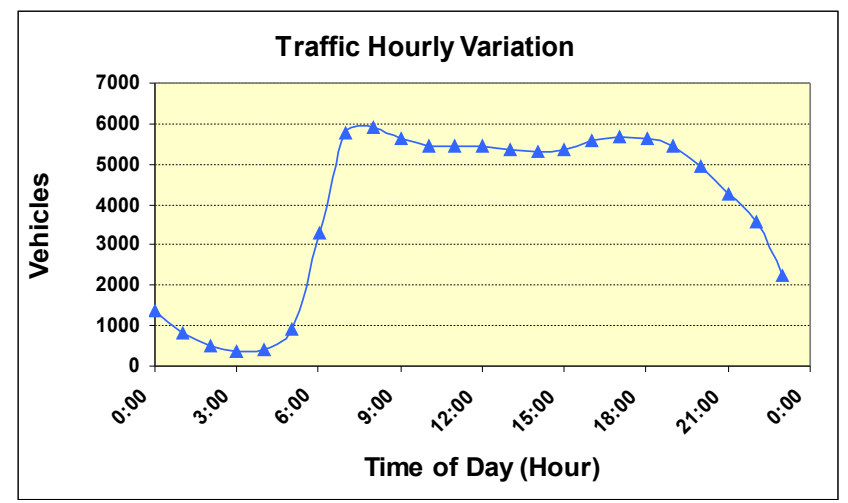

Figure 1: Average hourly variations of total vehicle flow in Gallery L1, Rebouças Tunnel, for the weekdays of 2002. 
Following the same approach adopted in the construction of the composite traffic flow for Rebouças, composite typical profiles were built for each pollutant. In a similar trend to what was observed for the traffic flow, the hourly variations for the pollutant concentration levels inside Gallery L1 exhibit a roughly flat profile or a rather insubstantial variation from day to day.

Figure 2 shows the composite plot for $\mathrm{CO}$ average concentrations. Figures 3-5 present the average composite ratios to $\mathrm{CO}$ for $\mathrm{NO}, \mathrm{SO}_{2}$ and $\mathrm{PM}_{10}$, respectively.

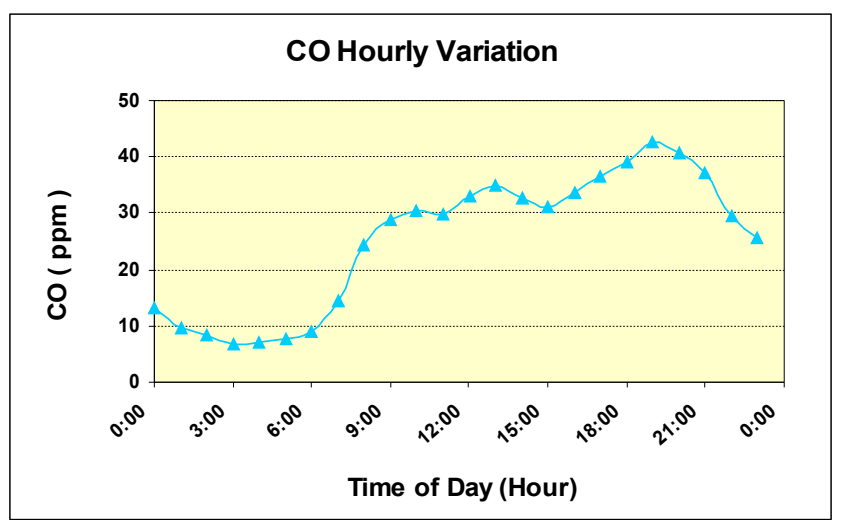

Figure 2: $\mathrm{CO}$ one-hour composite average concentrations in Gallery L1, Rebouças Tunnel, for the weekdays of 2002.

In terms of typical day cycles, as a rule, the highest concentration levels occur close to traffic peaks and the criteria pollutants show good overall correlation levels with $\mathrm{CO}$, as expected, given their common combustion-bound origin, justifying the presentation of their average concentration variations or estimates based upon simple linear regressions with $\mathrm{CO}$ measured values.

Mostly for all the criteria pollutants measured the correlation coefficient values $\left(r^{2}\right)$ obtained in the regressions with $\mathrm{CO}$ ranged roughly from about the 70 to roughly the $97 \%$ levels in the period.

On average $\mathrm{SO}_{2}$ and $\mathrm{PM}_{10}$ tend to present lower values of $\mathrm{r}^{2}$ levels, but still ranging above the $70 \%$ level. It is important to mention that, on average, for all the pollutants measured there were no substantial decreases in the recorded concentration levels, within the standard deviation limits, for the period of observations.

CO hourly averages ranged from 10 to 50 ppm roughly throughout all the year of 2002 . These relatively high values are consistent with the pollutant formation process, mainly due to the partial oxidation or incomplete fuel combustion, which is strongly influenced by the very intense traffic and its flow patterns inside Rebouças Tunnel. Factors such as cold start, deaccelerations, low speed levels, intense accelerations etc tend to maximize potential $\mathrm{CO}$ emissions due to average rich-fuel burning conditions.

The measured concentration levels are also a consequence of the location of the monitoring station (about $1.5 \mathrm{~km}$ inside the uphill tunnel gallery, thus potentially maximizing the emissions).

For the sake of an initial benchmarking, CO concentration levels obtained form this study early in 2002 were compared to the routine monitoring provided by the tunnel air quality control system, using electrochemical cell detectors, for the safety of both vehicle drivers and tunnel personnel, and showed excellent correlation values (above $85 \%$ level). NO concentration levels ranged from less than $1 \mathrm{ppm}$ to about $4 \mathrm{ppm}$ and this form is by far the dominant for nitrogen oxides (NOx) found in the tunnel, accounting for more than $90 \%$ of the sum of $\mathrm{NO}$ plus $\mathrm{NO}_{2}$.

The NO correlation levels with $\mathrm{CO}$ ranged from $0.78<r^{2}<0.95$, thus enabling estimates of $\mathrm{NO}$ emission levels based about CO measures.

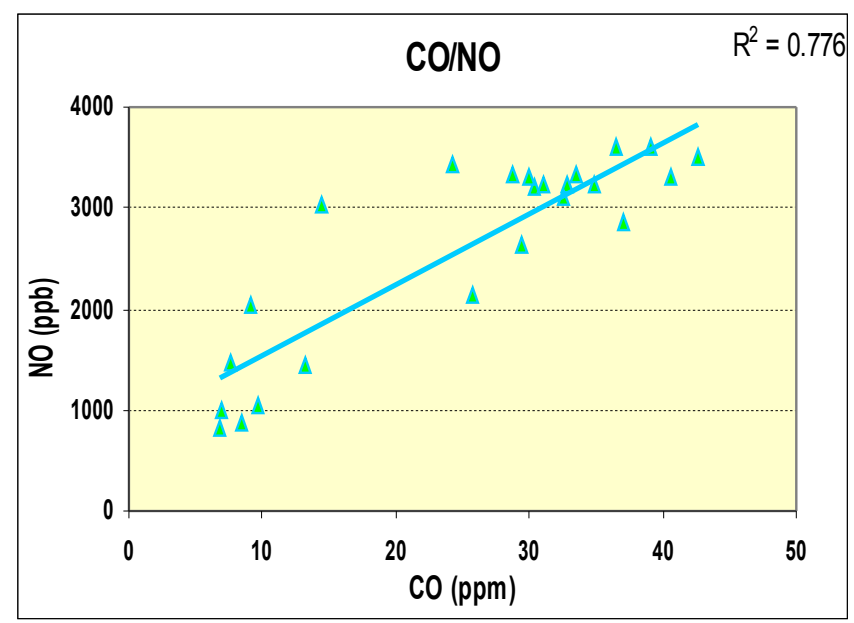

Figure 3: CO/NO ratios in Gallery L1, Rebouças Tunnel, for the weekdays of 2002.

Inhalable particles concentrations ranged from about 60 to $250 \mu \mathrm{g} \mathrm{m}^{-3}$, for the composite annual profiles. According to the official inventories (FEEMA, 2006) the prevailing apportion route of this pollutant to the urban atmospheres is through either HDV vehicles (burning diesel) or poorly maintained circulation 
arteries (ressuspension). In the case of Rebouças Tunnel, the dominant vehicle category is LDV, fired by lighter fuel blends, that tend to produce lower particle emissions.

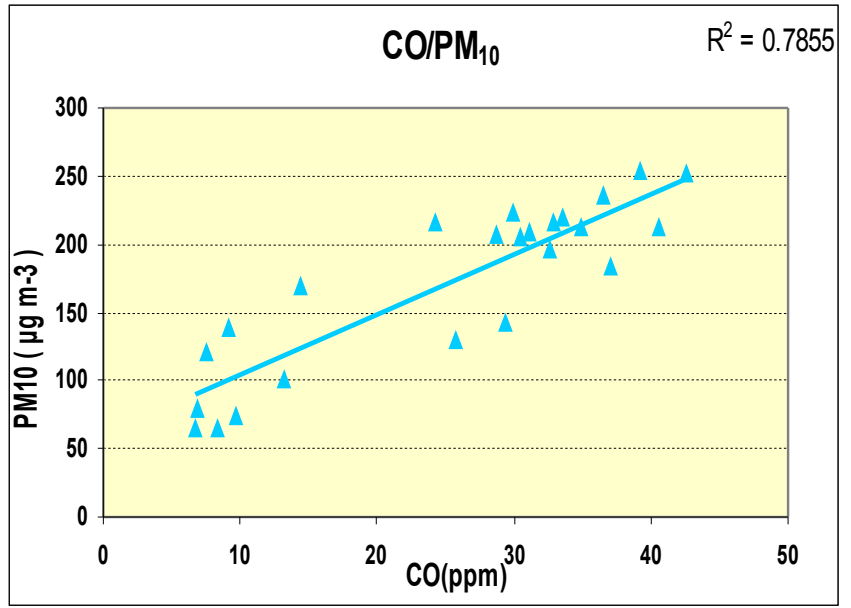

Figure 4: CO/PM 10 ratios in Gallery L1, Rebouças Tunnel, for the weekdays of 2002.

Sulfur oxides in Rebouças were measured as $\mathrm{SO}_{2}$ and showed a concentration variation range within the limits of 55 to roughly $140 \mathrm{ppb}$. The prevailing formation process is through the combustion of fuel-bound sulfur, more abundant in diesel than in the lighter motor fuels. This is consistent with the lower range for the observed correlation levels with $\mathrm{CO}$.

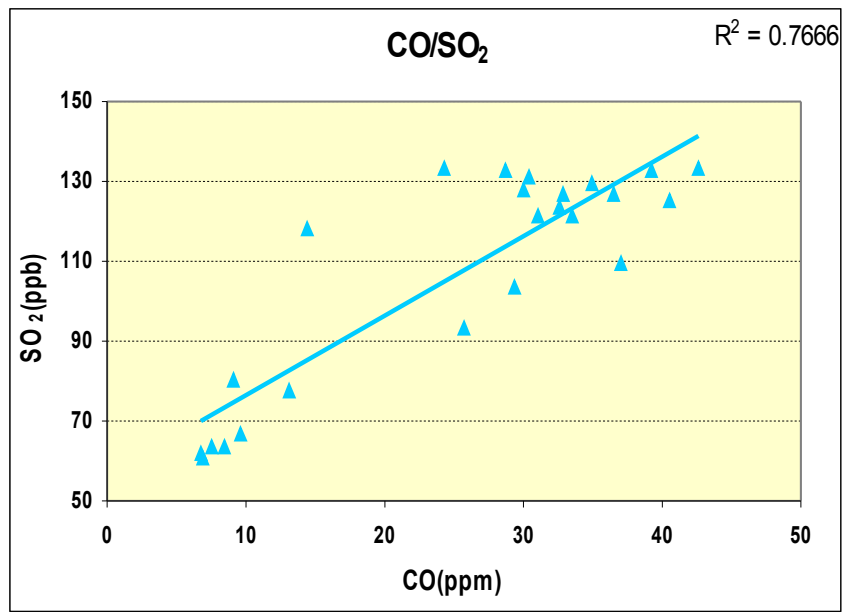

Figure 5: $\mathrm{CO} / \mathrm{SO}_{2}$ ratios in Gallery L1, Rebouças Tunnel, for the weekdays of 2002.

This study enabled the initial assessment of the current local active fleet emissions in Rio. The partial results up to now show good correlation levels of the main pollutants to $\mathrm{CO}$, as consistent with the vehicle-bound origins of these pollutants and also the prevalence of LDV within the local fleet.

The observed concentration levels for all the pollutants measured are elevated compared to typical values for Rio de Janeiro downtown, as consistent with the intensive traffic and the elevated percentage of traffic jams inside the tunnel, together with the location of the monitoring station. For example, for $\mathrm{CO}$, typical concentrations in Rio de Janeiro are lower than 2 ppm (FEEMA, 2006).

Results indicate a CO/NO ratio (on a ppm/ ppb basis) of 0.011 in good agreement with preliminary data for Janio Quadros Tunnel (0.018) and Maria Maluf Tunnel (0.011), in São Paulo, Brazil (Sanchez-Ccoyollo, 2002), and atmospheric data for open locals in Porto Alegre, Brazil (0.0101) (Grosjean et al., 1999) Córdoba, Argentina (0.0193-0.0218) (Olcese et al., 2001). A more recent result was obtained by Vivanco and Andrade (2006) for São Paulo (São Caetano do Sul station), the ratio being 0.0149 for 61 observations. These values may be considered as characteristic results for the LDV emission ratios in Brazil.

Emission ratios are important input data for urban atmospheric air quality models. Ozone concentrations depends on the initial amounts and emissions of volatile organic compound and NOx. Since ozone production does not increase linearly with an increase in the precursor concentrations, simulated results should be used in combination with ambient data to establish the relationships between emissions and pollutant concentrations.

Acknowledgments. The authors wish to express their gratitude to the Rebouças Tunnel Administration, the tunnel technicians and all personnel for their technical partnership, close collaboration and incentive to the monitoring campaigns throughout this project. 


\section{References}

1. DETRAN RJ, Rio de Janeiro State Traffic Authority. Availabe in: http://www.detran.rj.gov.br/ . Accessed in: January 2006.

2. FEEMA, State Environmental Agency. Fundação Estadual de Engenharia do Meio Ambiente, Rio de Janeiro. Available in: $\quad$ http://www.feema.rj.gov.br. Accessed in: January 2006.

3. HSIEH, C. C.; CHANG, K. H.; KAO, Y. S. Estimating the ozone formation potential of volatile organic aromatic compounds in vehicle tunnels. Chemosphere, 39, 1433, 1999.

4. CONAMA, Conselho Nacional de Meio Ambiente. Resolução 008/1990. Available in:http://www.mma.gov.br/port/conama /res/res90/res0890.html. Accessed in: January 2006.

5. ALMEIDA, J.C. Estudo do Comportamento de Poluentes em Ambientes Confinados: o Caso do Túnel Rebouças. 2004. Dissertação (Mestrado em Química) - Instituto de Química, Universidade Federal do Rio de Janeiro.

6. SANCHEZ-CCOYOLLO, O.R. Identificação da Contribuição das Fontes Locais e Remotas de Poluentes na Região Metropolitana de São Paulo. 2002. Tese (Doutorado em Ciências Atmosféricas) - Instituto de Astronomia, Geofísica e Ciências Atmosféricas, Universidade de São Paulo.

7. GROSJEAN, D.; GROSJEAN, E.; MOREIRA, L. F. R. Porto Alegre Air Quality Study. PETROBRAS Internal Reports. Porto Alegre, 1999.

8. OLCENSE, L., E; PALANCAR, G., G.; TOSELLI, B, M.; An Inexpensive Method to Estimate $\mathrm{CO}$ and NOx Emissons from Mobile Sources. Atmospheric Environment, 35, 6213, 2001.

9. VIVANCO, M.G.; ANDRADE, M.F.; Validation of the Emission Inventory in the São Paulo Metropolitan Area of Brazil based on Ambient Concentrations of CO, NMOG and NOx and on a Photochemical Model. Atmospheric Environment, 40, 1189, 2006. 